\title{
Short Communication \\ Use of Maldi-Tof MS biosensor in microbial assessment of Brazilian kefir grains ${ }^{1}$
}

\author{
Roberta Oliveira Viana², Karina Teixeira Magalhães-Guedes ${ }^{3 *}$ (D), Disney Ribeiro Dias ${ }^{4}$, Rosane Freitas Schwan ${ }^{2}$
}

$10.1590 / 0034-737 X 201966010010$

\begin{abstract}
The aim of this study was to evaluate the use of Maldi-Tof MS biosensor in microbial assessment of Brazilian kefir grains. Maldi-Tof MS is a new methodology for the rapid diagnosis of microorganisms. A total of 358 microorganisms were isolated, 31 were yeasts and 327 were bacteria (divided into lactic and acetic bacteria). Microbial colonies were grown in Luria-Bertani agar medium and incubated at $35^{\circ} \mathrm{C}$ for $18 \mathrm{~h}$ and used in the identification of species by MaldiTof MS. The microbial population identified in Brazilian kefir grains was Lactobacillus paracasei, Saccharomyces cerevisiae, Lactobacillus plantarum, Acetobacter pasteurianus, and Acetobacter syzygii. This study demonstrated a rapid and accurate identification of the Brazilian kefir grains microorganisms using the Maldi-Tof MS biosensor. In conclusion, the Maldi-Tof MS technology can facilitate the microbiological control in a fermentation process using kefir grains as starter cultures.
\end{abstract}

Keywords: microorganisms; bacteria's; yeast; biological sensor.

\section{RESUMO}

\section{Utilização do biossensor Maldi-Tof MS na avaliação de micro-organismos dos grãos de kefir brasileiro}

O objetivo deste estudo foi avaliar o uso do biossensor de Maldi-Tof MS na avaliação microbiana de grãos de kefir. Maldi-Tof MS é uma nova metodologia para o diagnóstico rápido de micro-organismos. Um total de 358 microorganismos foram isolados, 31 foram leveduras e 327 foram bactérias (divididas em bactérias láticas e acéticas). Colônias microbianas foram cultivadas em meio Luria-Bertani (LB) e incubadas a $35^{\circ} \mathrm{C}$ por $18 \mathrm{~h}$ e posteriormente utilizadas na identificação a nível de espécies pelo Maldi-Tof MS. A população microbiana identificada nos grãos de kefir brasileiros foi Lactobacillus paracasei, Saccharomyces cerevisiae, Lactobacillus plantarum, Acetobacter pasteurianus e Acetobacter syzygii. Este estudo demonstrou uma identificação rápida e precisa dos micro-organismos de grãos de kefir brasileiros utilizando o biossensor Maldi-Tof MS. Em conclusão, a tecnologia Maldi-Tof MS pode facilitar o controle microbiológico em um processo de fermentação usando grãos de kefir como culturas iniciadoras.

Palavras-chave: micro-organismos; bactérias; levedura; sensor biológico.

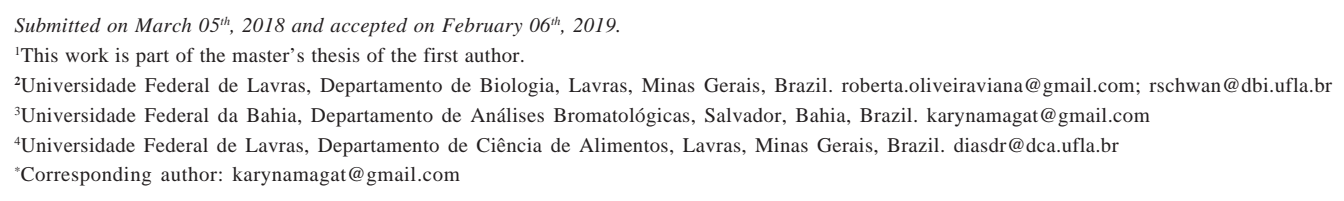




\section{INTRODUCTION}

Kefir is a polysaccharide grain containing microorganisms that produce fermented beverages, such as the traditional Turkish beverage also named "kefir", which is from milk, and has low alcohol content (Simova et al., 2002; Guzel-Seydim et al., 2005; Irigoyen et al., 2005; Magalhães et al., 2011a, 2011b, 2011c; Puerari et al., 2012; Cho et al., 2018). Kefir is a mixed culture of various yeasts and bacteria species combined in a matrix of proteins and polysaccharide "kefiran", which are formed during cell growth under aerobic conditions (Magalhães et al., 2010a, 2010b). The kefir grains are irregularly shaped and hard granules, with yellowish-white colour, which resemble miniature cauliflower blossoms (Corona et al., 2016).

In Brazil, kefir grains are used in private households (Magalhães et al., 2011c) and are added to different types of milk, such as cow, goat, or sheep, coconut, rice, and soy (Irigoyen et al., 2005; Magalhães et al., 2011c). The grains are responsible for the fermentation that produce lactic acid, acetic acid, $\mathrm{CO}_{2}$, alcohol (ethyl 2 alcohol), and aromatic compounds. These compounds provide the unique sensory characteristics of kefir: fizzy, acid taste, and tart and refreshing flavour (Corona et al., 2016).

The kefir beverage contains vitamins, minerals, and essential amino acids that help the body with healing and maintenance functions and contains easily digestible complete proteins (Roos et al., 2018). In accordance with Medrano et al. (2008), the benefits of consuming kefir in the diet are numerous, such as its antitumoral, (Vinderola et al., 2005), antimicrobial (Rodrigues et al., 2005), antiinflammatory, and antiallergical (Lee et al., 2007) activities. The composition of microbial species is an important factor to characterize the kefir therapeutic benefits (Simova et al., 2002; Guzel-Seydim et al., 2005; Irigoyen et al., 2005; Magalhães et al., 2011a, 2011b, 2011c; Cho et al., 2018). A rapid identification of the microorganisms is necessary in the fermentative process of kefir grains, which facilitates the microbiological control of fermentative processes on a large scale.

An optical technique with potential use to rapidly identify the microorganisms is the Maldi-Tof MS (Matrix Assisted Laser Desorption/Ionisation - Time of Flight Mass Spectrometry) (Microflex-Bruker Daltonics/ BioTyper $^{\mathrm{TM}}$ ) (Chang et al., 2016; Pasternak et al., 2012; Gaudreau et al., 2018; Mayoral et al., 2018). In this technique, the sample is uniformly mixed in a large quantity of matrix. The matrix absorbs the ultraviolet light (nitrogen laser light, wavelength $337 \mathrm{~nm}$ ) and converts it to heat energy. A small part of the matrix (down to $100 \mathrm{~nm}$ from the top outer surface of the Analyte in the diagram) heats rapidly (in several nano seconds) and is vaporized, together with the sample. Charged ions of various sizes are generated on the sample spot (Figure 1). A potential difference $\mathrm{V} 0$ between the sample slide and ground attracts the ions in the direction shown in the diagram. The velocity of the attracted ions $\mathrm{v}$ is determined by the law of conservation of energy. As the potential difference $\mathrm{V} 0$ is constant with respect to all ions, ions with smaller $\mathrm{m} / \mathrm{z}$ value (lighter ions) and more highly charged ions move faster through the drift space until they reach the detector. Consequently, the time of ion flight differs according to the mass-to-charge ratio $(\mathrm{m} / \mathrm{z})$ value of the ion. The method of mass spectrometry that exploits this phenomenon is called Time of Flight Mass Spectrometry (Pasternak et al., 2012; Mayoral et al., 2018).

The aim of this study was to evaluate the use of MaldiToF biosensor in the microbial assessment of Brazilian kefir grains, as well as to identify the microorganisms associated with them.

\section{MATERIAL AND METHODS}

\section{Kefir grains}

Brazilian kefir grains (Stock-culture of the Microbiology laboratory of the Federal University of Lavras, Brazil) were used in the experiments.

\section{Microbiological analysis}

We used Maldi-Tof MS biosensor (Microflex-Bruker Daltonics/BioTyper ${ }^{\mathrm{TM}}$ ) for the microbiological analysis. A total of 358 isolates were identified.

The isolation of microorganisms in kefir grains was performed according to Magalhães et al. (2011c). Bacteria and yeasts were enumerated by the surface spread technique, plating $100 \mu \mathrm{L}$ of each diluted sample in triplicate. Enumeration of microorganisms was carried out using four different culture media. Lactic acid bacteria (LAB) were enumerated on Nutrient Agar (Oxoid, S/P, Brazil), De Man, Rogosa, and Sharpe Agar (MRS) (Oxoid, S/P, Brazil) media. Acetic acid bacteria (AAB) were enumerated on 135 medium (DSMZ, Deutsche Sammlung von Mikroorganismen und Zellkulturen $\mathrm{GmbH}$, Germany). All media for bacterial enumeration were supplemented with $0.4 \mathrm{mg} \mathrm{mL}^{-1}$ nystatin (Sigma, St. Louis, USA). Yeasts were enumerated on yeast extract peptone glucose (YEPG) agar containing $100 \mathrm{mg}$ chloramphenicol (Sigma, St. Louis, USA) and $50 \mathrm{mg}$ chlortetracycline (Sigma, St. Louis, USA) to inhibit bacterial growth. After spreading, plates were incubated at $28^{\circ} \mathrm{C}$ for $48 \mathrm{~h}$ for bacteria and for five days for yeasts, colony forming units ( $\left.\log 10 \mathrm{CFU} \mathrm{mL}^{-1}\right)$ were quantified. For each type of medium containing isolated colonies, the square root of the number of colonies was taken at random for identification. 
For identification of microbial species of kefir grains by Maldi-Tof MS, the Escherichia coli K12 strain was used as external standard for calibration biosensor following the method described by Chang et al. (2016). Cell colonies were grown in Luria-Bertani (LB) agar medium and incubated at $35{ }^{\circ} \mathrm{C}$ for $18 \mathrm{~h}$. The microbial colonies were used in the identification by Maldi-Tof MS.

\section{RESULTS AND DISCUSSION}

Rapid diagnosis of microorganisms is decisive to guarantee adequate identification in biological samples. Biochemical methods are precise and sensitive, but rather slow. New resources are available to enable faster diagnosis, and the most promising is Maldi-Tof MS technology, applied to microbiological diagnosis by rapid method using the microbial colonies.

The microbial population count of the kefir grains performed in this study Found: lactic acid bacteria with a population of $8.10 \log \mathrm{CFU} \mathrm{mL} \mathrm{mL}^{-1}$ (approximately $10^{8}$ cells); $\mathrm{AAB}$ in a low population of $4.01 \log \mathrm{CFU} \mathrm{\textrm {mL } ^ { - 1 }}$ (approximately $10^{4}$ cells); and yeasts in population of 6.01 $\log \mathrm{CFU} \mathrm{mL} \mathrm{m}^{-1}$ (approximately $10^{6}$ cells). This microbial population is expected in the kefir grains because they are considered probiotic (Simova et al., 2002; Guzel-Seydim et al., 2005; Irigoyen et al., 2005; Magalhães et al., 2011a, 2011b, 2011c; Puerari et al., 2012; Cho et al., 2018).
A total of 358 microorganisms were isolated, 31 yeasts and 327 bacteria (divided into lactic and acetic bacteria). The isolates were identified by Maldi-Tof MS technique (Figure 1). The results showed higher population of

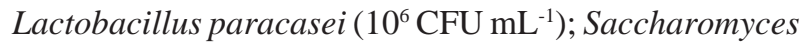
cerevisiae, Lactobacillus plantarum, Acetobacter pasteurianus, and Acetobacter syzygii were found in smaller quantities $\left(10^{4} \mathrm{CFU} \mathrm{mL} \mathrm{m}^{-1}\right)$ (Figure 2).

Quintilla et al. (2018) evaluated the efficiency of MaldiTof MS to identify foodborn yeasts. The identified yeasts were named as Rhodotorula babjevae, Meyerozyma caribbica, Clavispora lusitaniae, Debaryomyces hansenii, Candida oleophila, Pichia membranifaciens, Kazachstania telluris, and Mrakia frigida. Authors showed that Maldi-Tof MS is applicable for routine identification and validation of foodborne yeasts.

Gaudreau et al. (2018) evaluated Maldi-Tof MS to identify bacteria from biofilms. They compared three sample preparation procedures on biofilms grown in vitro. The extended direct transfer method was able to identify 13 isolates out of $18(72 \%)$ at the species level and 15 out of $18(83 \%)$ at the genus level.

Mayoral et al. (2018) reported two new cases involving immunocompetent girls with cervicofacial lymphadenitis due to Mycobacterium mantenii, and the reliability of Maldi-Tof MS for identifying Mycobacterium mantenii was efficient.
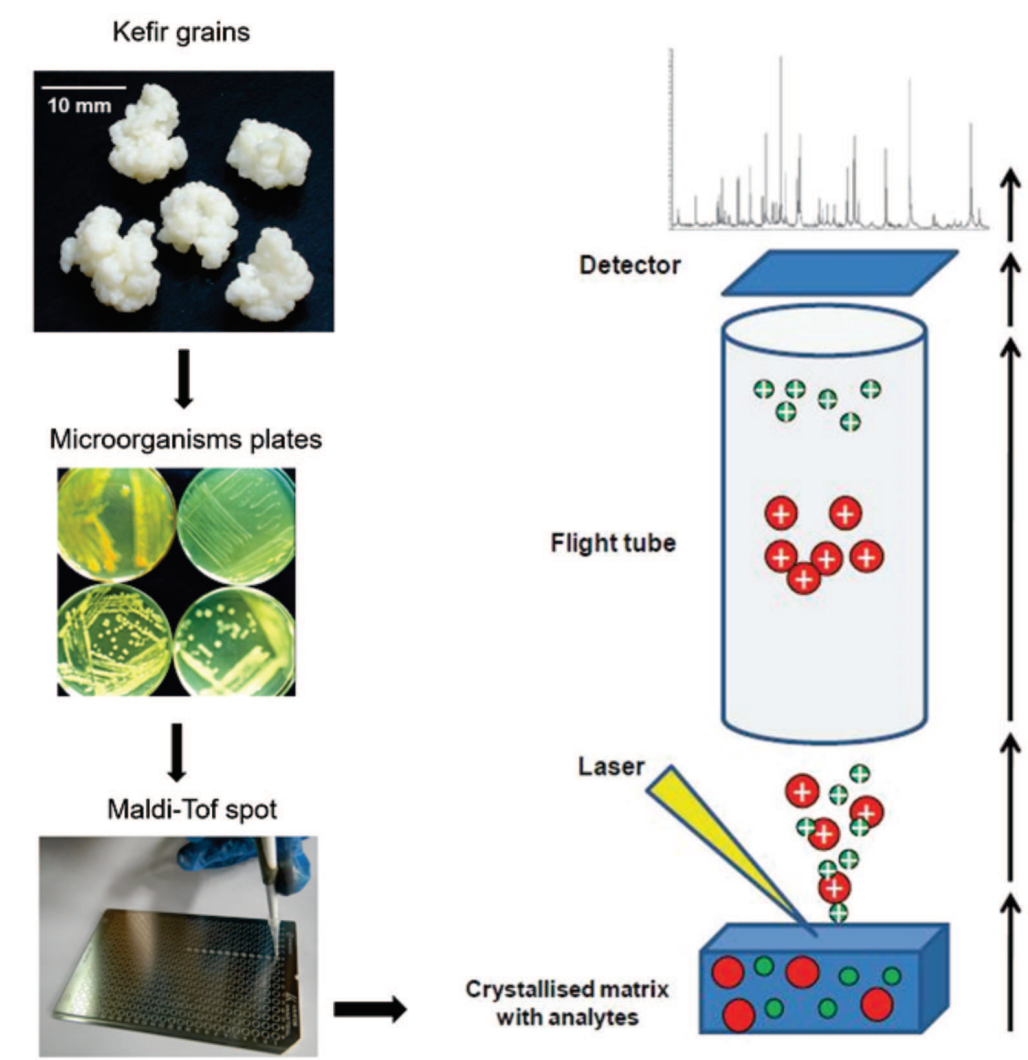

Result (spectrum)

Detection

Separation: TOF (no electric field)

Acceleration (electrostatic field)

Matrix-assisted laser desorption ionization (MALDI)

Figure 1: Brazilian kefir micoorganisms analysis methodology in the Maldi-Tof MS biosensor. 


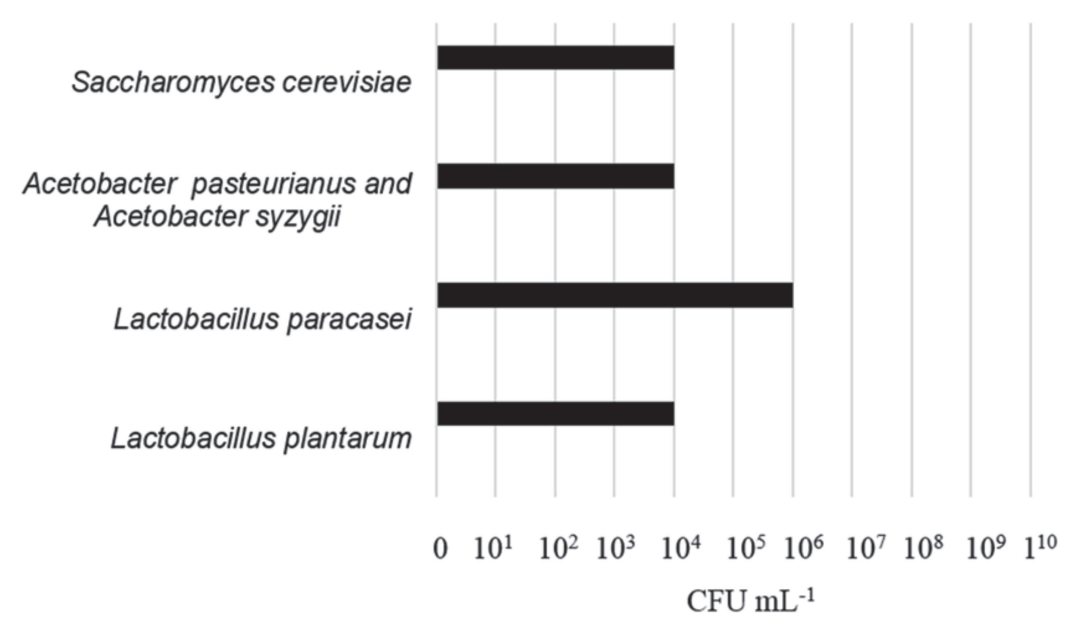

Figure 2: Microbial identification of Brazilian kefir grains by Maldi-Tof MS technique.

\section{CONCLUSION}

The Maldi-Tof MS technology proved to be useful for diagnosis of kefir microorganisms, allowing a fast and safe diagnosis for the scientific environment. The technology can facilitate the microbiological control in a fermentation process using kefir grains as starter cultures. The microorganisms identified in the Brazilian kefir are the same commonly found in kefir grains, with predominance of Lactobacillus paracasei.

\section{ACKNOWLEDGMENTS}

The authors thank the Brazilian agencies: Conselho Nacional de Desenvolvimento Científico e Tecnológico (CNPQ) and Coordenação de Aperfeiçoamento de Pessoal de Nível Superior (CAPES).

\section{REFERENCES}

Chang S, Carneiro-Leão MP, de Oliveira BF, Souza-Motta C, Lima N, Santos C \& de Oliveira NT (2016) Polyphasic approach including MALDI-TOF MS/MS analysis for identification and characterisation of Fusarium verticillioides in Brazilian corn kernels. Toxins, 8(3): 54-67.

Cho Y-J, Kim D-H, Jeong D, Seo K-H, Jeong HS, Lee HG \& Kim $\mathrm{H}$ (2018) Characterization of yeasts isolated from kefir as a probiotic and its synergic interaction with the wine byproduct grape seed flour/extract. LWT - Food Science and Technology, 90:535-539.

Corona O, Randazzo W, Miceli A, Guarcello R, Francesca N, Esten H, Moschetti G \& Settanni L (2016) Characterization of kefir-like beverages produced from vegetable juices. LWT Food Science and Technology, 66:572-581.

Gaudreau AM, Labrie J, Goetz C, Dufour S \& Jacques M (2018) Evaluation of MALDI-TOF mass spectrometry for the identification of bacteria growing as biofilms. Journal of Microbiological Methods, 145:79-81.

Guzel-Seydim Z, Wyffels JT, Seydim AC \& Greene AK (2005) Turkish kefir and kefir grains: microbial enumeration and electron microscobic observation. International Journal of Dairy Technology, 58:25-29.
Irigoyen A, Arana I, Castiella M, Torre P \& Ibáñez FC (2005) Microbiological, physicochemical, and sensory characteristics of kefir during storage. Food Chemistry, 90:613-620.

Lee MY, Ahn KS, Kwon OK, Kim MJ, Kim MK, Lee IY, Oh SR \& Lee HK (2007) Anti-inflammatory and anti-allergic effects of kefir in a mouse asthma model. Immunobiology, 212:647-654.

Magalhães KT, Dias DR, Pereira GVM, Oliveira JM, Domingues L, Teixeira JÁ, Silva JBA \& Schwan RF (2011a) Chemical composition and sensory analysis of cheese whey-based beverages using kefir grains as starter culture. International Journal of Food Science and Technology, 46:871-878.

Magalhães KT, Dragone G, Pereira GVM, Oliveira JM, Domingues L, Teixeira JÁ, Silva JBA \& Schwan RF (2011b) Comparative study of the biochemical changes and volatile compounds during the production of novel whey-based kefir beverages and traditional milk kefir. Food Chemistry, 126:249-253.

Magalhães KT, Pereira GVM, Campos CR, Dragone G \& Schwan RF (2011c) Brazilian kefir: structure microbial communities and chemical composition. Brazilian Journal of Microbiology, 42:693-702.

Magalhães KT, Pereira MA, Nicolau A, Dragone G, Domingues L, Teixeira JA Silva JBA \& Schwan RF (2010a) Production of fermented cheese whey-based beverage using kefir grains as starter culture: Evaluation of morphological and microbial variations. Bioresource Technology, 101:8843-8850.

Magalhães KT, Pereira GVM \& Schwan RF (2010b) Microbial communities and chemical changes during fermentation of sugary Brazilian kefir. World Journal of Microbiology and Biotechnology, 01:01-10.

Mayoral TN, Andrés AGA, Carretero SF, Fernández RC \& Pajares MSJ (2018) Cervicofacial lymphadenitis due to Mycobacterium mantenii: rapid and reliable identification by MALDI-TOF MS. New Microbes and New Infections, 22:01-03.

Medrano M, Pérez PF \& Abraham AG (2008) Kefiran antagonizes cytopathic effects of Bacillus cereus extracellular factors. International Journal of Food Microbiology, 122:01-07.

Pasternak J (2012) Novas metodologias de identificação de microorganismos: Maldi-Tof. Einstein, 10:118-119.

Puerari C, Magalhães KT \& Schwan RF (2012) New cocoa pulp-based kefir beverages: Microbiological, chemical composition and sensory analysis. Food Research International, 48:634-640. 
Quintilla R, Kolecka A, Casaregola S, Daniel HM, Houbraken J, Kostrzewa M, Boekhout T \& Groenewald M (2018) MALDITOF MS as a tool to identify foodborne yeasts and yeast-like fungi. International Journal of Food Microbiology, 266:109118.

Rodrigues KL, Caputo LRG, Carvalho JCT, Evangelista J \& Schneedorf JM (2005) Antimicrobial and healing activity of kefir and kefiran extract. International Journal of Antimicrobial Agents, 25:404-408.
Roos J \& Vuyst L (2018) Acetic acid bacteria in fermented foods and beverages. Current Opinion in Biotechnology, 49:115-119.

Simova E, Beshkova D, Angelov A, Hristozova TS, Frengova G \& Spasov Z (2002) Lactic acid bacteria and yeasts in kefir grains and kefir made from them. Journal Industrial of Microbiology and Biotechnology, 28:01-06.

Vinderola CG, Duarte J, Thangavel D, Perdigón G, Farnworth E \& Matar C (2005) Immunomodulating capacity of kefir. Journal of Dairy Research, 72:195-202. 